\title{
Endothelial progenitor cells participation in cardiovascular and kidney diseases: a systematic review
}

\author{
Jolanta Kiewisz ${ }^{1 凶}$, Monika M. Kaczmarek², Anna Pawlowska ${ }^{3}$, Zbigniew Kmiec ${ }^{1}$ and \\ Tomasz Stompor ${ }^{3}$
}

IFaculty of Medical Sciences, Department of Human Histology and Embryology, University of Warmia and Mazury in Olsztyn, Olsztyn, Poland; ${ }^{2}$ Institute of Animal Reproduction and Food Research, Polish Academy of Sciences, Olsztyn, Poland; ${ }^{3}$ Faculty of Medical Sciences Department of Nephrology, Hypertension and Internal Medicine, University of Warmia and Mazury in Olsztyn, Olsztyn, Poland

Endothelial progenitor cells (EPCs) represent a small population of blood cells $\left(5-40\right.$ cells $\left./ \mathrm{mm}^{3}\right)$, with an ability to differentiate into endothelial cells that form the lining of the blood vessels and contribute to postnatal angiogenesis. Abundant evidence shows that recruitment of EPCs from the bone marrow, the monocyte/macrophage lineage and the organs facilitate the endothelial regeneration and repair. Changes in the number of EPCs were observed in both, chronic kidney and cardiovascular diseases. Thus, these cells were tested for usage in diagnosis and therapy. In this paper, we review the current knowledge on the EPC biology and contribution of these cells to the kidney and cardiovascular diseases.

Key words: endothelial progenitor cells, chronic kidney diseases, cardiovascular diseases.

Received: 07 March, 2016; revised: 05 May, 2016; accepted: 18 May, 2016; available on-line: 30 June, 2016

\section{INTRODUCTION}

A single layer of squamous cells lining blood vessels, described as the endothelium, forms a natural barrier which separates blood and the connective tissue. Endothelial cells which build this layer are highly metabolically active, and play a critical role in many physiological processes, including the angiogenesis, hemodynamics, immunological reactions, control of the vasomotor tone, membrane permeability and trafficking of blood cells between blood and the underlying tissue (Aird et al., 2012; Fig. 1A). Endothelial cells also form a selective barrier in the kidney. Capillaries of the glomerulus are highly fenestrated, with 50- to 80-nm pores (Maezawa et al., 2015). These small blood vessels contribute to formation of the glomerular filtration barrier (Maezawa et al., 2015); a functional integrity of the glomerular endothelium is needed to protect against vascular diseases. Endothelial exposure to destructive factors progresses towards reduction of renal glomerular endothelial barrier, a pro-inflammatory pattern, senescence, and apoptosis of the endothelial cells (Jourde-Chiche et al., 2009). Moreover, the chronic kidney disease (CKD) increases endothelial activation and lesion, and decreases endothelial repair, leading to endothelial dysfunction (Jourde-Chiche et al., 2009; Fig. 1B). However, repair processes can be conducted by circulating or resident progenitor cells (Hillebrands et al., 2002) which may include endothelial progenitor cells (EPCs).

The EPCs represent a small population of blood cells with an ability to differentiate into endothelial cells and participate in the postnatal angiogenesis. They also contribute to the regeneration of endothelium in different diseases, including those with advanced kidney and cardiovascular disorders. CKD, defined as gradual loss of renal function, is highly proatherogenic and results in exposing patients to a very high cardiovascular morbidity. This in turn results in markedly increased cardiovascular (CVS) mortality, which is elevated from $30-60 \%$ in the early stages of CKD. In the end-stage renal disease (ESRD; patients that need dialysis or kidney transplantation), it may exceed by 10 - to 80 - fold the mortality observed in the general population (O'Hare et al., 2007; Rifkin et al., 2010; Dalrymple et al., 2011). In this paper, we review recent data from experimental and clinical studies, investigating the potential of EPCs in the endothelial repair and contribution to cardiovascular disease (CVD), with special attention to patients with CKD.

\section{EPCS BIOLOGY}

\section{Isolation, characterization, quantification}

Low oxygen level and the presence of chemoattractant-like stromal cell-derived factor (SDF-1/CXCL12) present an excellent environment for EPCs in bone marrow (BM). EPCs dwell in stem cell niches and may be released into the circulation upon certain stimuli (Lin et al., 2000). In the blood, the number of circulating EPCs

e-mail: jolanta.kiewisz@uwm.edu.pl

Abbreviations: CKD, chronic kidney disease; EPCs, endothelial progenitor cells; CVS, cardiovascular; ESRD, end-stage renal disease; CVD, cardiovascular disease; SDF-1/CXCL12, chemoattractant-like stromal cell-derived factor; BM, bone marrow; vWF, von Willebrand factor; PBMCs, peripheral blood mononuclear cells; VEGF, vascular endothelial growth factor; VEGFR2, vascular endothelial growth factor receptor; $K D R$, kinase insert domain receptor; HUVEC, umbilical vascular endothelial cells; Dil-Ac-LDL, fluorescently-labeled lowdensity lipoprotein; UEA-1, Ulex eurapaeus agglutinin-1; eNOS, endothelial nitric oxide synthase; NO, nitric oxide; ADMA, asymmetric dimethyl-arginine; EPO, erythropoietin; $A C E$, angiotensin converting enzyme; $A R B$, angiotensin II receptor blocking; GM-CSF, granulocyte/macrophage colony stimulating factor; SPC, smooth muscle progenitor cells; GFR, glomerular filtration rate; PLGF, placental growth factor; MCP-1, monocyte chemoattractant protein-1; IL $1 \beta$, interleukin $1 \beta$; CAPD, continuous ambulatory peritoneal dialysis; $H D$, hemodialysis; IAA, indole-3-acetic acid; $\beta 2 \mathrm{~m}, \beta 2$-microglobulin; IL 8, interleukin 8; RAAS, renin-angiotensin-aldosterone system; CCA-IMT, common carotid artery intima-media thickness; CFU, colony forming units; IL 6, interleukin 6, hsCRP, high-sensitive C-reactive protein; PAl-1, plasminogen activator inhibitor; TNFa, tumor necrosis factor alpha; EMP, endothelial microparticles; AKI, acute kidney injury. 

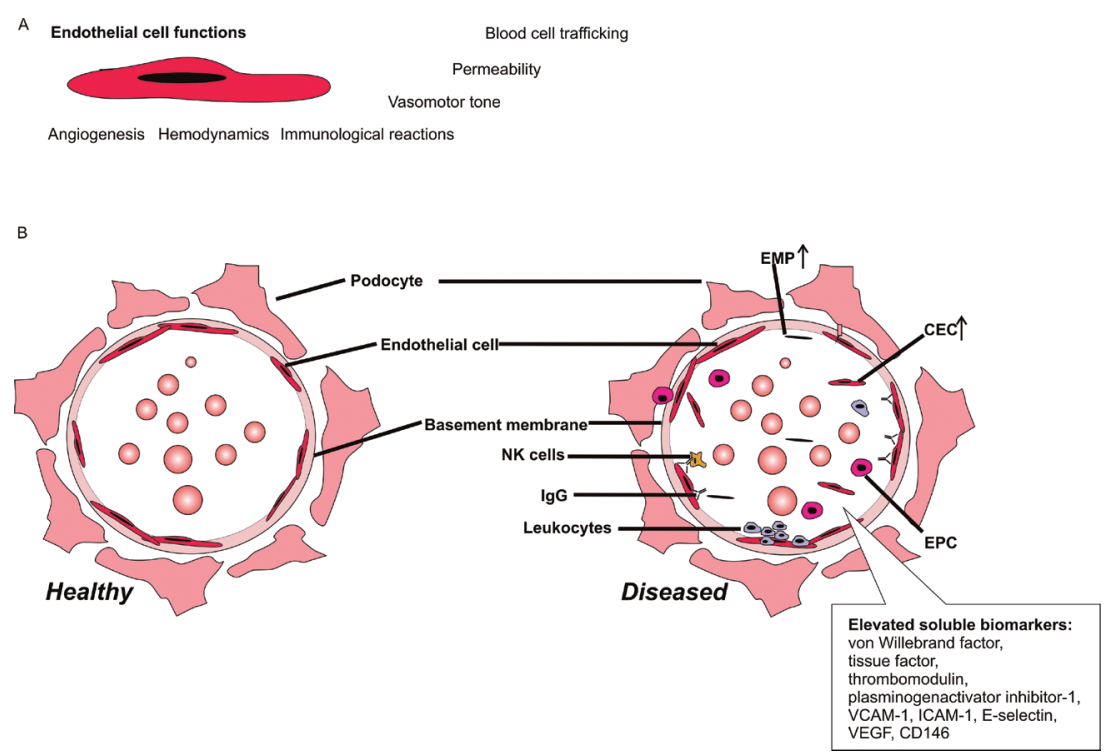

Figure 1. Endothelial cell functions (A) and endothelial glomerular barrier in a healthy and dysfunctional state (B).

Antibody-dependent cellular cytotoxicity and aggregates of leukocytes in the capillary lumen indicate microvascular inflammation (Sis et al., 2012). Increased $(\uparrow)$ number of circulating endothelial microparticles (EMP), circulating endothelial cells (CEC) and soluble biomarkers secreted by activated endothelial cells are depicted (Jourde-Chiche et al., 2011). Endothelial progenitor cells (EPC) were marked.

ranges between 5 and 40 cells $/ \mathrm{mm}^{3}$ (Vasa et al., 2001). However, they can be also derived from the monocyte/ macrophage lineage and migrate from the walls of aorta, arteries and veins of liver, prostate, heart, kidney, testes and lungs (Caplice \& Doyle, 2005). They were detected in all tunica's of vascular wall (Goligorsky et al., 2014).

In the first report, published in 1997, Asahara and coworkers (1997) had described BM-derived CD34+/ VEGFR-2+ monocyte cell population collected from peripheral blood.

EPCs are distinguished based on the identification of CD34, VEGFR2 and CD133 surface markers (Urbich \& Dimmeler, 2004; Fig. 2). The CD34 antigen is used to identify hematopoietic progenitors, while KDR/ VEGFR2 expression on the EPCs surface suggests their ability to differentiate into endothelium (Urbich \& Dimmeler, 2004). The CD133 antigen is typical for less ma- tured EPCs (Urbich \& Dimmeler, 2004). Other markers co-expressed on the EPCs surface that characterize their 'endothelial' potential include the von Willebrand factor (vWF), CD31 and CD144 (Urbich \& Dimmeler, 2004). CD34-/CD133+/VEGFR-2 ${ }^{+}$, CD34 ${ }^{+} / \mathrm{CD} 133^{+} / \mathrm{VEGFR}^{2}{ }^{+}$ and $\mathrm{CD}_{34}{ }^{+} / \mathrm{CD} 133^{-} / \mathrm{VEGFR}-2^{+}$cells represent defined subpopulations of EPCs (Friedrich et al., 2006). Moreover, the CD34-/CD133+/VEGFR-2+ cells are considered to be precursors of $\mathrm{CD}_{3} 4^{+} / \mathrm{CD} 133^{+} / \mathrm{VEGFR}_{-}{ }^{+}$ cells. The CD34-/CD133+ subpopulation has a much greater potential for regeneration than their mature form, and the cells representing this subpopulation are preferably recruited in such processes as ischemia and vascular injury in the unstable human coronary artery disease and experimental limb ischemia model (Friedrich et al., 2006).

The differences in the EPCs number can clearly be noticed between men and women throughout different

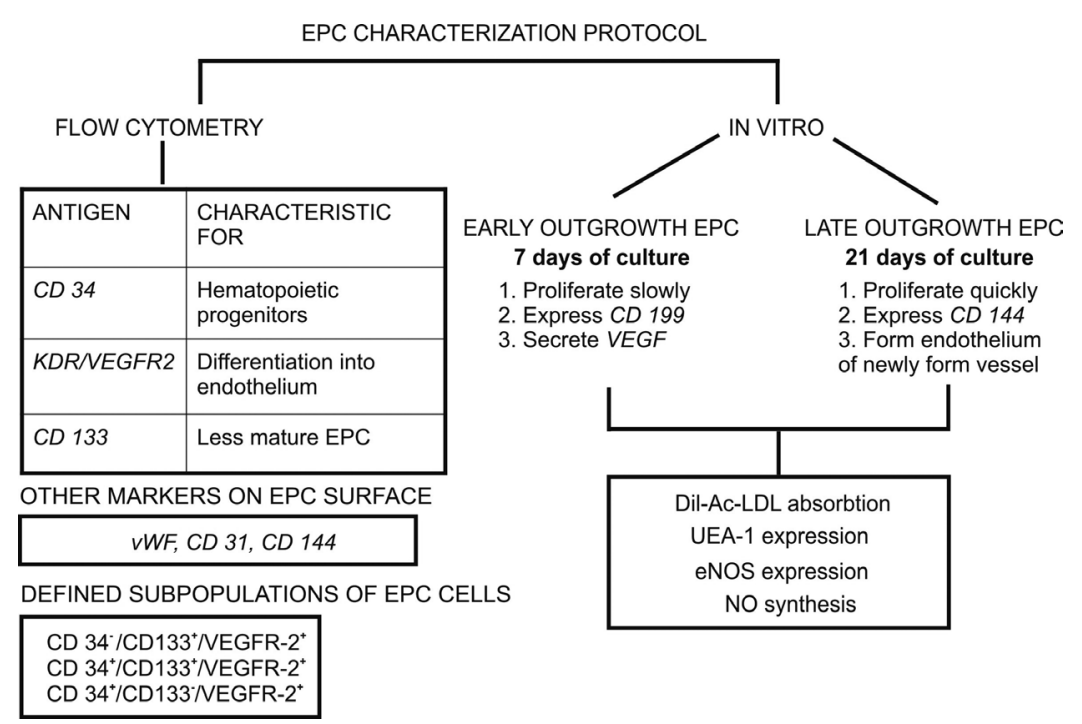

Figure 2. Scheme presenting methods of EPC isolation and characterization.

VEGFR, vascular endothelial growth factor receptor; Dil-Ac-LDL, fluorescently-labeled low-density lipoprotein; UEA-1, Ulex eurapaeus agglutinin-1 antigen; eNOS, endothelial nitric oxide synthase; NO, nitric oxide. 
Table 1. Potential agents affecting EPCs recruitment and mobilization

\begin{tabular}{|c|c|c|}
\hline & Factors & References \\
\hline \multicolumn{3}{|l|}{ Activators } \\
\hline \multirow{9}{*}{ Intrinsic factor/condition } & Low oxygen level & Hoffmann et al., 2013 \\
\hline & Mechanical endothelial damage & Werner et al., 2003 \\
\hline & Ischemia & Takahashi et al., 1999 \\
\hline & Physical exercise & Laufs et al., 2004 \\
\hline & Cytokine release & Takahashi et al., 1999 \\
\hline & VEGF & Xiao et al., 2007 \\
\hline & Stromal-derived growth factor 1 & Xiao et al., 2007 \\
\hline & Granulocyte/macrophage colony stimulating factor & Xiao et al., 2007 \\
\hline & Uric acid & Westerweel et al., 2007 \\
\hline \multirow{7}{*}{ Drug } & Angiotensin converting enzyme (ACE) inhibitors & Xiao et al., 2007 \\
\hline & Angiotensin II receptor blocking agents (ARBs) & Yu et al., 2008 \\
\hline & Erythropoietin & Bahlman et al., 2004 \\
\hline & Insulin & Dong et al., 2011 \\
\hline & Glitazones & Pistrosch et al., 2005 \\
\hline & Statins & Dimmeler et al., 2001; Xiao et al., 2007 \\
\hline & Hormone replacement therapy & Xiao et al., 2007 \\
\hline \multicolumn{3}{|l|}{ Inhibitors } \\
\hline \multirow{4}{*}{ Intrinsic factor/condition } & Age & Park et al., 2014 \\
\hline & Reduced levels of high-density lipoprotein cholesterol & Park et al., 2014 \\
\hline & Higher bone erosion scores & Park et al., 2014 \\
\hline & Angiotensin II & Endtmann et al., 2011 \\
\hline \multirow{4}{*}{ Drugs } & Sirolimus & Banerjee et al., 2012 \\
\hline & Paclitaxel & Banerjee et al., 2012 \\
\hline & Cyclosporine A & Wang et al., 2008 \\
\hline & Steroids & Bahlman et al., 2010 \\
\hline
\end{tabular}

periods of life (Fadini et al., 2008). Xiao and coworkers (2007) demonstrated a significantly lower number of circulating EPCs in females, as compared to males at a corresponding age. Higher numbers of circulating EPCs were detected in fertile women as compared to men, however, no sex differences could be detected after menopause (Fadini et al., 2008). As EPCs display alpha and beta forms of estrogen receptors, the numbers of EPCs change in the menstrual cycle phase- and estrogen-dependent manner. Moreover, it was shown that the EPCs participated more effectively in compensatory angiogenesis in women than in men (Fadini et al., 2008).

Populations of EPCs can be also identified in in vitro cultures (Fig. 2). Early-outgrowth EPCs obtained from a fraction of peripheral blood mononuclear cells (PBMCs), separated from the whole blood with the Ficoll gradient method, appear after 7 days of culture (Ingram et al., 2004). The cells proliferate slowly, express CD133 antigen and may secrete chemotactic, growth factor substances known to stimulate angiogenesis (vascular endothelial growth factor; VEGF; Ingram et al., 2004). The EPCs that appear in the culture on about the 21st day (called the late-outgrowth EPCs) have a high proliferative potential, express CD144 antigen, can directly incorporate into endothelia of newly formed vessels and form tube-like structures when merged in culture with human umbilical vascular endothelial cells (HUVEC; Laschke et al., 2011). Both, late- and early-outgrowth EPCs, absorb the modified, fluorescently-labeled low-density lipoprotein (Dil-Ac-LDL) and display the UEA-1 (Ulex eurapaeus agglutinin-1) antigen on their surfaces (Asahara et al., 1997). Moreover, EPCs express endothelial nitric oxide synthase (eNOS) gene and protein, and synthesize nitric oxide (NO) upon in vitro stimulation with VEGF (Bahlman et al., 2010). Asymmetric dimethyl-arginine (ADMA) significantly suppresses eNOS activity in cultured EPCs and this effect is abolished by statin (Thum et al., 2005). Moreover, rosuvastatin, the statin with the highest potential to reduce LDL-cholesterol serum level, decreases ADMA levels in a culture and this effect is accompanied by enhanced colony forming potential of EPCs (Thum et al., 2005). EPCs with impaired ability to form 'tube-like structures', when co-cultured with HUVEC, restore this function after addition of rosuvastatin (Thum et al., 2005). 


\section{Mobilization, inflammation, recruitment}

Several factors that mobilize the EPCs from bone marrow and/or vascular niches have been identified. Decrease in the level of oxygen (Hoffmann et al., 2013), mechanical damage of endothelia (Werner et al., 2003), ischemia (Takahashi et al., 1999), physical exercise (Laufs et al., 2004), cytokine release (Takahashi et al., 1999), VEGF (Xiao et al., 2007), erythropoietin (Epo; Bahlmann et al., 2004), stromal derived growth factor 1 (SDF-1; Xiao et al., 2007), granulocyte/macrophage colony stimulating factor (GM-CSF) (Xiao et al., 2007) and variations in uric acid serum concentration (Westerweel et al., 2007) are among the most important stimuli. Moreover, a potential to activate or suppress the mobilization and activation of EPCs has been also identified for several drugs (Table 1).

A normal number of circulating EPCs is considered as a marker of 'endothelial health' and regenerative potential of the endothelium. A high number of EPCs in peripheral blood may also indicate ongoing endothelial damage, transient restricted inflammatory response or persistent/excessive inflammatory stimulation. EPCs exposed to oxidative stress pass through mitochondrial disintegration, which results in DNA destabilization and telomeres' shortening (Satoh et al., 2009; Giannotti et al., 2010; Carracedo et al., 2011). Upon challenge with the above mentioned initiators, EPCs move into the sites of inflammation and injury where they roll, adhere to the endothelial damaged area and contribute to endothelial repair (Vajkoczy et al., 2003). It seems that no more than $1 \%$ to $20 \%$ of circulating EPCs has the potential to directly incorporate into an injured vascular wall (Urbich et al., 2003). Fusion of EPCs with damaged, although still viable endothelial cells, has been also postulated but this mechanism appears unlikely to significantly contribute to the endothelial repair (Goligorsky et al., 2010). Most probably, EPCs attracted to the neighborhood of a damaged epithelium exert their regenerative effect in a paracrine way, i.e. releasing substances that promote and enhance the repair processes (Goligorsky et al., 2010).

\section{EPCS IN THE CHRONIC KIDNEY DISEASE}

In general, in many clinical studies, a decreased number of circulating EPCs was observed in patients with CKD. A marked reduction in the number of circulating CD $34^{+}$EPCs in the blood, when compared to healthy controls, was observed in stages 1 and 2 of CKD (Krenning et al., 2009). Moreover, the number of CD34+ decreased with the disease progression (Krenning et al., 2009). However, Jie and coworkers (2010) did not observed a correlation between the degree of kidney dysfunction, the cause of disease and the CKD stage. A significantly lower number of EPCs (CD34+/VEGFR-2 ${ }^{+}$ cells), but not smooth muscle progenitor cells (SPC), was demonstrated in CKD patients, as compared with healthy controls (which was the lowest among patients with $\mathrm{GFR}<30 \mathrm{~mL} / \mathrm{min} / 1.73 \mathrm{~m}^{2}$ and cardiovascular co-morbidity (Jie et al., 2010)). A strong, inverse relationship between GFR and the number of circulating SPC was observed (Jie et al., 2010).

ESRD and low serum albumin were the predictors for lower number of EPCs (Chen et al., 2013). Patients with ESRD had higher number of late outgrowth EPCs which could directly participate in re-endothelialisation and new vessel formation ('Zhao et al., 2014). However, impairment of EPCs function in the course of CKD progression was observed in vitro with an increased thrombin production (Krenning et al., 2009). In ESRD patients, the late outgrowth EPCs had higher proliferative potential in comparison to early outgrowth EPCs (Zhao et al., 2014), and this correlated with angiogenesis factor like placental growth factor (PLGF), monocyte chemoattractant protein-1 (MCP-1) and interleukin $1 \beta$ levels (IL1ß; Zhao et al., 2014).

\section{Dialysis}

Most of the studies on the role of EPCs in a renal disease were performed in patients with advanced CKD, i.e. in the pre-dialysis period and in those on dialysis. The number of EPCs was significantly lower among patients with ESRD on maintenance hemodialysis (HD), when compared to healthy controls Jourde-Chiche et al., 2011). HD patients were also characterized by a significantly lower number of EPCs in the blood that were CD34/VEGFR-2 double-positive and that had a potential to incorporate into endothelia (type $1 \mathrm{EPCs}$ ) under in vitro conditions. Type 2 EPCs derived from the HD subjects were characterized by a reduced potential to form cultures in vitro and had a decreased ability to produce angiogenic factors (VEGF) facilitating endothelial regeneration, than type 2 EPC derived from healthy control (Westerweel et al., 2007).

Dialysis modality (continuous ambulatory peritoneal dialysis - CAPD and HD) also influences the number of circulating EPCs in patients with ESRD (Ueno et al., 2010). CAPD patients were characterized with higher numbers of circulating EPCs when compared to subjects on HD, after gender adjustment (Ueno et al., 2010). Associations were also found between the number of EPCs and dialysis adequacy, as well as erythropoietin administration. The higher the dose of dialysis (extended or daily HD) or EPO, the higher the level of EPCs was observed (Krenning et al., 2009; Jourde-Chiche et al., 2011). In HD patients, a lower number of EPCs could also be associated with accelerated atherosclerosis (Ueno et al., 2010). Analysis of the association between EPCs and survival in the ESRD patients treated with HD revealed that CVS event-free survival and all-cause survival were prolonged in patients with a higher level of circulating progenitor cells (CD34+; Maruyama et al., 2008).

Uremic toxins are responsible for alterations in vascular progenitor cell differentiation, impaired endothelial regeneration and susceptibility to atherosclerosis (Westerweel et al., 2007). Uremic toxicity adversely affected progenitor cells in the early stages of kidney dysfunction and in ESRD (Jie et al., 2010). However, dialysis assisted removal of uremic toxins did not affect the EPCs number (Krieter et al., 2010). In patients with sepsis and elevated serum creatinine, increased uric acid serum level had been identified as a strong stimulus of EPCs mobilization (Patschan et al., 2011). However, the proliferative potential of EPCs was reduced in this disease setting independently from the creatinine level (Patschan et al., 2011).

The number of $\mathrm{CD}_{3} 4^{+} / \mathrm{CD} 133^{+}$progenitor cells negatively correlated with serum indole-3-acetic acid (IAA) and $\beta 2$-microglobulin $(\beta 2 \mathrm{~m})$ levels Jourde-Chiche et al., 2011). Uremic serum containing IAA blocked the EPCs differentiation and functional activity in vitro, leading simultaneously to an increased apoptosis of cultured EPCs (de Groot et al., 2004; Jourde-Chiche et al., 2011). In HD patients who developed ESRD as the result of chronic glomerulonephritis, hypertensive nephropathy or diabetic kidney disease, the serum levels of IL- 8 and SDF-1 were increased when compared to healthy volunteers (Ribeiro 
et al., 2014). After an in vitro exposure of endothelial cells harvested from the HD patients to uremic toxins, the cellular expression of SDF-1 decreased, while the expression of IL-8 was increased (Ribeiro et al., 2014).

\section{Kidney transplantation}

Successful kidney transplantation leads to an increase in $\mathrm{CD}_{3} 4^{+} / \mathrm{VEGFR} 2^{+}$and $\mathrm{CD} 133^{+} / \mathrm{VEGFR} 2^{+}$cell numbers in the blood (Herbrig et al., 2006; Di Marco et al., 2011), and renal graft functions positively correlated with the number of circulating EPCs (de Groot et al., 2005). Kidney transplant recipients were characterized with a higher number of circulating EPCs, when compared to the gender and aged-matched hypertensive subjects with preserved renal function. In renal transplant patients, no correlations were observed between the EPCs number and the use of statins or renin-angiotensin-aldosterone system (RAAS) blocking agents. Plasma SDF-1 level in patients with functioning renal graft was increased when compared to patients with an essential hypertension and normal kidney function (Di Marco et al., 2011). Indices of endothelial dysfunction related to hyperemia were associated with a reduced EPCs number and an increased serum parathyroid hormone concentration (Fatini et al., 2012).

\section{EPCS IN CARDIOVASCULAR DISEASE}

EPCs are considered to be promising biomarkers of cardiovascular health (Fadini et al., 2008). However, some authors postulated that no correlation exists between EPCs subpopulations and remodeling of the arterial vessel wall (Sibal et al., 2009), and that no direct link can be documented between changes in the EPCs number and development of CVD (Xiao et al., 2007).

EPCs may protect against atherogenesis and their importance is greater when the process of vascular damage is ongoing (Xiao et al., 2007; Fadini et al., 2008). The number of EPCs was a strong and independent negative predictor of the presence of atherosclerotic plaque in the common carotid artery (Lau et al., 2007; Fadini et al., 2008). The number of $\mathrm{CD} 34^{+} / \mathrm{KDR}^{+}$cells was diminished with the presence and advancement of preclinical atherosclerosis and the risk factors constituted a reduction in aortic and femoral sites, but not in carotid circulation (Friedrich et al., 2006).

A higher common carotid artery intima-media thickness (CCA-IMT), a higher ADMA level and a lower percentage of EPCs within the total peripheral blood monocyte population, when compared with healthy controls, were observed in patients with rheumatoid arthritis, the disease considered as highly proatherogenic (Surdacki et al., 2007). Moreover, a low number of circulating $\mathrm{CD}^{+} / \mathrm{KDR}^{+}$cells and an increase in serum ADMA were predictors of the GFR loss in patients with a coronary artery disease (Surdacki et al., 2010). The EPCs number was lower in patients on HD than in healthy controls, or in patients with coronary artery disease with preserved renal function (Schlieper et al., 2008). There was no association between the EPCs number, and such parameters of vascular damage as an increased pulse wave velocity or advancement of coronary calcification (Schlieper et al., 2008).

Men with a certain cardiovascular risk, but without clinically overt CVD, were characterized with inversed correlation between the number of EPCs colony forming units (CFU) in culture and the Framingham Risk Score, a well-documented clinical scale to assess the risk for development of the CVS disease (Hill et al., 2003). The number of EPC-CFU was in turn positively associated with a change in the brachial artery reactivity in response to an increased blood flow, a parameter reflecting the function of endothelium (Hill et al., 2003). When comparing patients with low, intermediate and high number of EPCs, those with the highest number of the mentioned cells were the healthiest (being younger, having lower total- and LDL- cholesterol, and lower prevalence of hypertension or diabetes; Hill et al., 2003).

Hypertensive patients are at a higher risk for development of CKD (Hsu et al., 2013). In patients with hypertension who developed microalbuminuria or macroalbuminuria, a decreased circulating EPCs number could be found; this finding may be associated with progression of atherosclerosis and a higher cardio-vascular risk (Huang et al., 2010). In patients with atherosclerotic renal artery stenosis, who were on a limited sodium intake and were using an appropriate antihypertensive regimen, function of the circulating EPCs, sampled from the renal vein, was well preserved (Chen et al., 2014). A unilateral renal artery stenosis which induced renovascular hypertension in the pig model, increased the EPCs migration, proliferation, potential for tube formation, and VEGF and eNOS expression in vitro (Zhu et al., 2011). SDF-1 was demonstrated to attract EPCs to the sites of injury in the porcine model of renovascular hypertension (Zhu et al., 2011). An increased expression of SDF-1, angiopoietin-1, Tie-2 and c-kit was detected in EPCs isolated from animals with experimental atherosclerotic renal artery stenosis (Chade et al., 2010).

Diabetes still remains one of the most important risk factors for development of atherosclerosis. Patients with type 1 diabetes are characterized with a significantly elevated markers of chronic inflammation (i.e. interleukin 6 [IL 6], high-sensitive C-reactive protein [hsCRP], plasminogen activator inhibitor [PAI-1], and tumor necrosis factor alpha (TNF $\alpha$; Lau et al., 2007). This proinflammatory cytokine profile was shown to be associated with a significantly reduced number of the following EPCs:

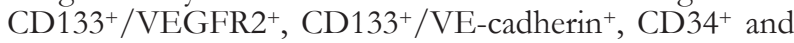
$\mathrm{CD}_{133^{+}}$cells. The number of EPCs was also significantly decreased in patients with the history of stroke, when compared to healthy controls (Lau et al., 2007). Post-ischemic brachial flow-mediated dilation, a measure of the preserved endothelial function, inversely correlated with the number of several subpopulations of EPCs, namely $\mathrm{CD} 4^{+} / \mathrm{VE}$-cadherin ${ }^{+}, \mathrm{CD} 133^{+} / \mathrm{VEGFR}^{+}$and CD34+ cells (Sibal et al., 2009).

\section{EPCS IN DIAGNOSIS AND THERAPY}

The number of EPCs in the blood can be used as a factor for predicting the patients' outcome. It can be considered as a marker of active non-specific inflammation, corresponding to endogenous vascular repair capacity in the presence of an endothelial injury (SchmidtLucke et al., 2005). Dysfunctional EPCs may result in an impaired ability to repair the endothelial damage (Schmidt-Lucke et al., 2005). Association between "endothelial health", as reflected by the circulating EPCs and CCA-IMT, may illustrate the usefulness of the EPCs assessment in diagnosis and monitoring of atherosclerosis (Fadini et al., 2006; Friedrich et al., 2006; Lau et al., 2007; Xiao et al., 2007).

Reduction of $\mathrm{CD} 34^{+} / \mathrm{KDR}^{+}$cells to below $0.0038 \%$ of the total circulating peripheral blood mononuclear cells (PBMC) was associated with a 6-fold higher 
risk for development of CVS, event over a 20-month follow-up period (Schmidt-Lucke et al., 2005). In the group of 587 patients with angiography-proven coronary artery disease, those with the highest likelihood to remain event-free (mortality and combined endpoint comprising of myocardial infarction, hospitalization, a need for coronary revascularization procedure) were characterized with the highest level of EPCs (Werner et al., 2005). However, assessment of the circulating EPCs number failed to predict death caused by an acute myocardial infarction or stroke (Werner et al., 2005).

Vesiculation of the membrane of endothelial cells that are damaged or undergo apoptosis, leads to the formation of endothelial microparticles (EMP), which have an important modulatory role in inflammation, coagulation, and vascular function. The higher EMP/EPC ratio in patients with hypertension was related to the risk of GFR loss (Hsu et al., 2013). Thus, therapies aimed at increasing the circulating EPCs number may have potential usefulness in preventing progression of the hypertensive kidney disease (Hsu et al., 2013). Moreover, assessing longitudinal changes in the EMP/EPC ratio may become a biomarker allowing prediction of the CKD progression.

The improvement of 'local' and 'systemic' parameters reflecting the kidney function were observed during sepsis and adriamycin-induced acute kidney injury (AKI) following intrarenal transplantation of the EPCs embedded within hyaluronic acid hydrogels (Ratliff \& Goligorsky, 2013). Such a procedure improved cortical and medullary microcirculation, reduced proteinuria, decreased serum creatinine and ameliorated interstitial fibrosis (Ratliff \& Goligorsky, 2013). In addition, blood pressure was stabilized and hepatic release of aminotransferases was reduced, while the release of anti-inflammatory and pro-angiogenic molecules was enhanced (Ratliff \& Goligorsky, 2013).

It seems likely that the fate of different progenitor cells is not fully determined even after releasing from the bone marrow, and under certain conditions these cells can change their phenotype into 'regenerative' or may alternatively contribute to the further damage of the vascular wall (Westerweel et al., 2007). Intrarenal infusion of autologous EPCs led to a new vessel formation, mainly in the outer renal cortex (Chade et al., 2010). Liang and coworkers found that injection of EPCs derived from a human Wharton's jelly, into the renal sub-capsular region, resulted in improvement in renal microcirculation, reduced the number of apoptotic cells and decreased expression of certain inflammatory cytokines (macrophage inflammatory protein-2 and keratinocyte-derived cytokine; Liang et al., 2014). Acute kidney injury was characterized with a reduction in renal capillary density which may lead to the development of renal fibrosis (Liang et al., 2014). Thus, transplantation of human Wharton's jelly-derived EPCs into renal sub-capsular space may be considered as a powerful therapeutic method for recovery of microvascular function which was shown in mice (Liang et al., 2014). However, establishing of an effective route of cell delivery into the diseased kidney in humans still remains a challenge (Liang et al., 2014).

The bulk of data clearly shows that measuring the circulating EPCs level may provide a clinically useful insight into the present status of endothelia, although the interpretation and real clinical significance of these findings still remain the matters of debate.

\section{SUMMARY}

Taken together, EPCs participate and play an important role in both, cardiovascular and kidney disease. However, the question about their structural and functional homogeneity, regenerative potential, significance, and therapeutic use still remains opened. Larger clinical studies with long-term follow-up and with implementation of objective methods of EPC effect quantification are needed to confirm significance of the EPCs in therapy.

\section{Acknowledgements}

Partially financed by a statutory grant of the Faculty of Medical Sciences, University of Warmia and Mazury in Olsztyn (1501.0801).

\section{Conflict of interest}

All of the authors have declared no competing interests.

\section{REFERENCES}

Aird WC (2012) Endothelial cell heterogeneity. Cold Spring Harb Perspect Med 2: a006429. http://dx. doi.org/10.1101/cshperspect.a006429.

Asahara T, Murohara T, Sullivan A, Silver M, van der Zee R, Li T, Witzenbichler B, Schatteman G, Isner JM (1997) Isolation of putative progenitor endothelial cells for angiogenesis. Science 14: 964 967. http://dx.doi.org/10.1126/science.275.5302.964.

Bahlmann FH, De Groot K, Spandau JM, Landry AL, Hertel B, Duckert T, Boehm SM, Menne J, Haller H, Fliser D (2004) Erythropoietin regulates endothelial progenitor cells. Blood 1: 921-926. http:// dx.doi.org/10.1182/blood-2003-04-1284.

Bahlman FH, Speer T, Fliser D (2010) Endothelial progenitor cells in chronic kidney disease. Nephrol Dial Transplant 25: 341-346. http:// dx.doi.org/10.1093/ndt/gfp643.

Banerjee S, Xu H, Fuh E, Nguyen KT, Garcia JA, Brilakis ES, Bhatt DL (2012) Endothelial progenitor cell response to antiproliferative drug exposure. Atherosclerosis 225: 91-98. http://dx.doi. org/10.1016/j.atherosclerosis.2012.08.025.

Caplice NM, Doyle B (2005) Vascular progenitor cells: origin and mechanisms of mobilization, differentiation, integration, and vasculogenesis. Stem Cells Dev 14: 122-139. http://dx.doi.org/10.1089/ scd.2005.14.122.

Carracedo J, Merino A, Briceño C, Soriano S, Buendía P, Calleros L, Rodriguez M, Martín-Malo A, Aljama P, Ramírez R (2011) Carbamylated low-density lipoprotein induces oxidative stress and accelerated senescence in human endothelial progenitor cells. FASEB J 25: 1314-1322. http://dx. doi.org/10.1096/fj.10-173377.

Chade AR, Zhu XY, Krier JD, Jordan KL, Textor SC, Grande JP, Lerman A, Lerman LO (2010) Endothelial progenitor cells homing and renal repair in experimental renovascular disease. Stem Cells 28: 1039-1047. http://dx. doi.org/10.1002/stem.426.

Chen YT, Cheng BC, Ko SF, Chen CH, Tsai TH, Leu S, Chang HW, Chung SY, Chua S, Yeh KH, Chen YL, Yip HK (2013) Value and level of circulating endothelial progenitor cells, angiogenesis factors and mononuclear cell apoptosis in patients with chronic kidney disease. Clin Exp Nephrol 17: 83-91. http://dx.doi.org/10.1007/ s10157-012-0664-9

Chen Z, Herrmann SM, Zhu X, Jordan KL, Gloviczki ML, Lerman A, Textor SC, Lerman LO (2014) Preserved function of late-outgrowth endothelial cells in medically treated hypertensive patients under well-controlled conditions. Hypertension 64: 808-814. http://dx.doi. org/10.1161/HYPERTENSIONAHA.114.03720.

Dalrymple LS, Katz R, Kestenbaum B, Shlipak MG, Sarnak MJ, Stehman-Breen C, Seliger S, Siscovick D, Newman AB, Fried L (2011) Chronic kidney disease and the risk of end-stage renal disease versus death. J Gen Intern Med 26: 379-385. http://dx. doi. org/10.1007/s11606-010-1511-x.

de Groot K, Bahlmann FH, Sowa J, Koenig J, Menne J, Haller H, Fliser D (2004) Uremia causes endothelial progenitor cell deficiency. Kidney Int 66: 641-646. doi:10.1111/j.1523-1755.2004.00784.x.

de Groot K, Bahlmann FH, Bahlmann E, Menne J, Haller H, Fliser D (2005) Kidney graft function determines endothelial progenitor cell number in renal transplant recipients. Transplantation 79: 941-945.

Di Marco GS, Rustemeyer P, Brand M, Koch R, Kentrup D, Grabner A, Greve B, Wittkowski W, Pavenstädt H, Hausberg M, Reuter S, Lang D (2011) Circulating endothelial progenitor cells in 
kidney transplant patients. PLoS One 6:e24046. http://dx. doi.org/ 10.1371/journal.pone.0024046.

Dimmeler S, Aicher A, Vasa M, Mildner-Rihm C, Adler K, Tiemann M, Rütten H, Fichtlscherer S, Martin H, Zeiher AM (2001) HMG$\mathrm{CoA}$ reductase inhibitors (statins) increase endothelial progenitor cells via the PI 3-kinase/Akt pathway. J Clin Invest 108: 391-397. http://dx. doi.org/ 10.1172/JCI13152.

Dong L, Kang L, Ding L, Chen Q, Bai J, Gu R, Li L, Xu B (2011) Insulin modulates ischemia-induced endothelial progenitor cell mobilization and neovascularization in diabetic mice. Microvasc Res 82: 227-236. http://dx. doi.org/ 10.1016/j.mvr.2011.09.006.

Endtmann C, Ebrahimian T, Czech T, Arfa O, Laufs U, Fritz M, Wassmann K, Werner N, Petoumenos V, Nickenig G, Wassmann S (2011) Angiotensin II impairs endothelial progenitor cell number and function in vitro and in vivo: implications for vascular regeneration. Hypertension 58: 394-403. http://dx. doi.org/ 10.1161/HYPERTENSIONAHA.110.169193.

Fadini GP, Coracina A, Baesso I, Agostini C, Tiengo A, Avogaro A, de Kreutzenberg SV (2006) Peripheral blood CD34+KDR+ endothelial progenitor cells are determinants of subclinical atherosclerosis in a middle-aged general population. Stroke 37: 2277-2282. doi: 10.1161/01.STR.0000236064.19293.79.

Fadini GP, de Kreutzenberg S, Albiero M, Coracina A, Pagnin E, Baesso I, Cignarella A, Bolego C, Plebani M, Nardelli GB, Sartore S, Agostini C, Avogaro A (2008) Gender differences in endothelial progenitor cells and cardiovascular risk profile: the role of female estrogens. Arterioscler Thromb Vasc Biol 28: 997-1004. http://dx. doi. org/ 10.1161/ATVBAHA.107.159558.

Fatini C, Sticchi E, Cesari F, Gori AM, Cioni G, De Stefano M, Bertoni E, Paudice N, Salvadori M, Zanazzi M, Abbate R (2012) Relationship among endothelial response to hyperemia, bone marrow-derived progenitor cells, and parathyroid hormone in renal transplantation. Transplantation 27: 835-841. http://dx. doi.org/ 10.1097/TP.0b013e318247a75d.

Friedrich EB, Walenta K, Scharlau J, Nickenig G, Werner N (2006) CD34-/CD133+/VEGFR-2+ endothelial progenitor cell subpopulation with potent vasoregenerative capacities. Circ Res 17: 98: e20-5. http://dx. doi.org/ 10.1161/01.RES.0000205765.28940.93.

Giannotti G, Doerries C, Mocharla PS, Mueller MF, Bahlmann FH, Horvàth T, Jiang $\mathrm{H}$, Sorrentino SA, Steenken N, Manes C, Marzilli M, Rudolph KL, Lüscher TF, Drexler H, Landmesser U (2010) Impaired endothelial repair capacity of early endothelial progenitor cells in prehypertension: relation to endothelial dysfunction. Hypertension 55: 1389-1397. http://dx.doi.org/10.1161/HYPERTENSIONAHA.109.141614.

Goligorsky MS, Yasuda K, Radcliff B (2010) Dysfunctional endothelial progenitor cells in chronic kidney disease. J Am Soc Nephrol 21: 911-919. http://dx. doi.org/ 10.1681/ASN.2009111119.

Goligorsky MS (2014) Endothelial progenitor cells: from senescence to rejuvenation. Semin Nephrol 34: 365-373. http://dx.doi. org/10.1016/j.semnephrol.2014.06.003.

Herbrig K, Gebler K, Oelschlaegel U, Pistrosch F, Foerster S, Wagner A, Gross P, Passauer J (2006) Kidney transplantation substantially improves endothelial progenitor cell dysfunction in patients with end-stage renal disease. Am J Transplan 6: 2922-2928. http://dx. doi.org 10.1111/j.1600-6143.2006.01555.x.

Hill JM, Zalos G, Halcox JP, Schenke WH, Waclawiw MA, Quyyumi AA, Finkel T (2003) Circulating endothelial progenitor cells, vascular function, and cardiovascular risk. $N$ Engl J Med 348: 593-600. http://dx.doi.org/10.1056/NEJMoa022287.

Hillebrands JL, Klatter FA, van Dijk WD, Rozing J (2002) Bone marrow does not contribute substantially to endothelial-cell replacement in transplant arteriosclerosis. Nat Med 8: 194-195. http://dx.doi. org/10.1038/nm0302-194.

Hoffmann BR, Wagner JR, Prisco AR, Janiak A, Greene AS (2013) Vascular endothelial growth factor-A signaling in bone marrow-derived endothelial progenitor cells exposed to hypoxic stress. Physiol Genomics 45: 1021-1034. http://dx.doi.org/ 10.1152/physiolgenomics.00070.2013.

Hsu CY, Huang PH, Chiang CH, Leu HB, Huang CC, Chen JW, Lin SJ (2013) Increased circulating endothelial apoptotic microparticle to endothelial progenitor cell ratio is associated with subsequent decline in glomerular filtration rate in hypertensive patients. PLoS One 12; 8: e68644. http://dx. doi.org/10.1371/journal.pone.0068644.

Huang PH, Huang SS, Chen YH, Lin CP, Chiang KH, Chen JS, Tsai HY, Lin FY, Chen JW, Lin SJ (2010) Increased circulating CD31+/ annexin $\mathrm{V}+$ apoptotic microparticles and decreased circulating endothelial progenitor cell levels in hypertensive patients with microalbuminuria. J Hypertens 28: 1655-1656. http://dx. doi.org/ 10.1097/ HJH.0b013e32833a4d0a.

Ingram DA, Mead LE, Tanaka H, Meade V, Fenoglio A, Mortell K, Pollok K, Ferkowicz MJ, Gilley D, Yoder MC (2004) Identification of a novel hierarchy of endothelial progenitor cells using human peripheral and umbilical cord blood. Blood 10: 2752-2760. http:// dx.doi.org/10.1182/blood-2004-04-1396.
Jie KE, Zaikova MA, Bergevoet MW, Westerweel PE, Rastmanesh M, Blankestijn PJ, Boer WH, Braam B, Verhaar MC (2010) Progenitor cells and vascular function are impaired in patients with chronic kidney disease. Nephrol Dial Transplant 25: 1875-1882. http://dx.doi. org/ $10.1093 / \mathrm{ndt} / \mathrm{gfp} 749$

Jourde-Chiche N, Dou L, Sabatier F, Calaf R, Cerini C, Robert S, Camoin-Jau L, Charpiot P, Argiles A, Dignat-George F, Brunet P (2009) Levels of circulating endothelial progenitor cells are related to uremic toxins and vascular injury in hemodialysis patients. $J$ Thromb Haemost 7: 1576-1584. http://dx.doi.org/ 10.1111/j.15387836.2009.03540.x

Jourde-Chiche N, Dou L, Cerini C, Dignat-George F, Brunet P (2011) Vascular incompetence in dialysis patients--protein-bound uremic toxins and endothelial dysfunction. Semin Dial 24: 327-337. http:// dx.doi.org/ 10.1111/j.1525-139X.2011.00925.x.

Krenning G, Dankers PY, Drouven JW, Waanders F, Franssen CF, van Luyn MJ, Harmsen MC, Popa ER (2009) Endothelial progenitor cell dysfunction in patients with progressive chronic kidney disease. Am J Physiol Renal Physiol 296: F1314-1322. http://dx.doi.org/ 10.1152/ajprenal.90755.2008.

Krieter DH, Fischer R, Merget K, Lemke HD, Morgenroth A, Canaud B, Wanner C (2010) Endothelial progenitor cells in patients on extracorporeal maintenance dialysis therapy. Nephrol Dial Transplant 25: 4023-4031. http://dx.doi.org/ 10.1093/ndt/gfq552.

Liang CJ, Shen WC, Chang FB, Wu VC, Wang SH, Young GH, Tsai JS, Tseng YC, Peng YS, Chen YL (2015) Endothelial progenitor cells derived from Wharton's jelly of human umbilical cord attenuate ischemic acute kidney injury by increasing vascularization and decreasing apoptosis, inflammation, and fibrosis. Cell Transplant 24: 1363-1377. http://dx.doi.org/10.3727/096368914X681720.

Laschke MW, Giebels C, Menger MD (2011) Vasculogenesis: a new piece of the endometriosis puzzle. Hum Reprod Update. 17: 628-636. http://dx.doi.org/ 10.1093/humupd/dmr023.

Lau KK, Chan YH, Yiu KH, Li SW, Tam S, Lau CP, Kwong YL, Tse HF (2007) Burden of carotid atherosclerosis in patients with stroke: relationships with circulating endothelial progenitor cells and hypertension. J Hum Hypertens 21: 445-451. http://dx.doi.org/ 10.1038/ sj.jhh. 1002178 .

Laufs U, Werner N, Link A, Endres M, Wassmann S, Jürgens K, Miche E, Böhm M, Nickenig G (2004) Physical training increases endothelial progenitor cells, inhibits neointima formation, and enhances angiogenesis. Circulation 109: 220-226. http://dx.doi.org/ 10.1161/01.CIR.0000109141.48980.37.

Lin Y, Weisdorf DJ, Solovey A, Hebbel RP (2000) Origins of circulating endothelial cells and endothelial outgrowth from blood. J Clin Invest 105: 71-77. http://dx.doi.org/10.1172/JCI8071.

Maezawa Y, Takemoto M, Yokote K (2015) Cell biology of diabetic nephropathy: Roles of endothelial cells, tubulointerstitial cells and podocytes. I Diabetes Investig 6: 3-15. http://dx.doi.org/10.1111/ jdi.12255.

Maruyama S, Taguchi A, Iwashima S, Ozaki T, Yasuda K, KikuchiTaura A, Soma T, Ishii H, Murohara T, Takahashi H, Kasuga H, Kumada Y, Toriyama T, Ito Y, Kawahara H, Yuzawa Y, Matsuo S (2008) Low circulating CD34+ cell count is associated with poor prognosis in chronic hemodialysis patients. Kidney Int 74: 16031609. http://dx.doi.org/10.1038/ki.2008.495.

O'Hare AM, Choi AI, Bertenthal D, Bacchetti P, Garg AX, Kaufman JS, Walter LC, Mehta KM, Steinman MA, Allon M, McClellan WM, Landefeld CS (2007) Age affects outcomes in chronic kidney disease. I Am Soc Nephrol 18: 2758-2765. http://dx.doi.org/10.1681/ ASN.2007040422.

Park YJ, Kim JY, Park J, Choi JJ, Kim WU, Cho CS (2014) Bone erosion is associated with reduction of circulating endothelial progenitor cells and endothelial dysfunction in rheumatoid arthritis. Arthritis Rheumatol 66: 1450-1460.

Patschan SA, Patschan D, Temme J, Korsten P, Wessels JT, Koziolek M, Henze E, Müller GA (2011) Endothelial progenitor cells (EPC) in sepsis with acute renal dysfunction (ARD). Crit Care 15: R94. http://dx.doi.org/10.1186/cc10100.

Pistrosch F, Herbrig K, Oelschlaegel U, Richter S, Passauer J, Fischer S, Gross P (2005) PPARgamma-agonist rosiglitazone increases number and migratory activity of cultured endothelial progenitor cells. Atherosclerosis 183: 163-167. http://dx.doi.org/j.atherosclerosis.2005.03.039.

Ratliff BB, Goligorsky MS (2013) Delivery of EPC embedded in HA-hydrogels for treatment of acute kidney injury. Biomatter 3. pii: e23284. http://dx.doi.org /10.4161/biom.23284.

Ribeiro V, Bosquetti B, Gonçalves SM, Bucharles SG, Rempel L, Maciel RA, de Oliveira RB, Pecoits-Filho R, Stinghen AE (2014) Uremic serum inhibits in vitro expression of chemokine SDF-1: impact of uremic toxicity on endothelial injury. I Bras Nefrol 36: 123-131. http://dx.doi.org/10.5935/0101-2800.20140021.

Rifkin DE, Katz R, Chonchol M, Fried LF, Cao J, de Boer IH, Siscovick DS, Shlipak MG, Sarnak MJ (2010) Albuminuria, impaired kidney function and cardiovascular outcomes or mortality in 
the elderly. Nephrol Dial Transplant 25: 1560-1567. http://dx.doi. org/10.1093/ndt/gfp646.

Satoh M, Minami Y, Takahashi Y, Tabuchi T, Itoh T, Nakamura M (2009) Effect of intensive lipid-lowering therapy on telomere erosion in endothelial progenitor cells obtained from patients with coronary artery disease. Clin Sci (Lond) 116: 827-835. http://dx.doi. org/10.1042/CS20080404.

Schlieper G, Hristov M, Brandenburg V, Krüger T, Westenfeld R, Mahnken AH, Yagmur E, Boecker G, Heussen N, Gladziwa U, Ketteler M, Weber C, Floege J (2008) Predictors of low circulating endothelial progenitor cell numbers in haemodialysis patients. Nephrol Dial Transplant 23: 2611-2618. http://dx.doi.org/10.1093/ ndt/gfn103.

Schmidt-Lucke C, Rössig L, Fichtlscherer S, Vasa M, Britten M, Kämper U, Dimmeler S, Zeiher AM (2005) Reduced number of circulating endothelial progenitor cells predicts future cardiovascular events: proof of concept for the clinical importance of endogenous vascular repair. Circulation 111: 2981-2987. http://dx.doi.org/0.1161/ CIRCULATIONAHA.104.504340.

Sibal L, Aldibbiat A, Agarwal SC, Mitchell G, Oates C, Razvi S, Weaver JU, Shaw JA, Home PD (2009) Circulating endothelial progenitor cells, endothelial function, carotid intima-media thickness and circulating markers of endothelial dysfunction in people with type 1 diabetes without macrovascular disease or microalbuminuria. Diabetologia 52: 1464-1473. http://dx.doi.org/10.1007/s00125-009-1401-0.

Sis B (2012) Endothelial molecules decipher the mechanisms and functional pathways in antibody-mediated rejection. Hum Immunol 73: 1218-1225. http://dx.doi.org/10.1016/j.humimm.2012.07.332.

Surdacki A, Martens-Lobenhoffer J, Wloch A, Marewicz E, Rakowski T, Wieczorek-Surdacka E, Dubiel JS, Pryjma J, Bode-Böger SM (2007) Elevated plasma asymmetric dimethyl-L-arginine levels are linked to endothelial progenitor cell depletion and carotid atherosclerosis in rheumatoid arthritis. Artbritis Rheum 56: 809-819. http://dx.doi.org/10.1002/art.22424.

Surdacki A, Marewicz E, Wieczorek-Surdacka E, Rakowski T, Szastak G, Pryjma J, Dudek D, Dubiel JS (2010) Synergistic effects of asymmetrical dimethyl-L-arginine accumulation and endothelial progenitor cell deficiency on renal function decline during a 2-year follow-up in stable angina. Nephrol Dial Transplant 25: 2576-2583. http://dx.doi.org/ 10.1093/ndt/gfp439.

Takahashi T, Kalka C, Masuda H, Chen D, Silver M, Kearney M, Magner M, Isner JM, Asahara T (1999) Ischemia- and cytokineinduced mobilization of bone marrow-derived endothelial progenitor cells for neovascularization. Nat Med 5: 434-438. http://dx.doi. org $/ 10.1038 / 7434$

Thum T, Tsikas D, Stein S, Schultheiss M, Eigenthaler M, Anker SD, Poole-Wilson PA, Ertl G, Bauersachs J (2005) Suppression of endothelial progenitor cells in human coronary artery disease by the endogenous nitric oxide synthase inhibitor asymmetric dimethylarginine. J Am Coll Cardiol 46: 1693-1701. http://dx.doi.org/10.1016/j. jacc.2005.04.066.

Ueno H, Koyama H, Fukumoto S, Tanaka S, Shoji T, Shoji T, Emoto M, Tahara H, Tsujimoto Y, Tabata T, Nishizawa Y (2010) Dialysis modality is independently associated with circulating endothelial progenitor cells in end-stage renal disease patients. Nephrol Dial Transplant 25: 581-586. http://dx.doi.org/10.1093/ndt/gfp358.
Urbich C, Heeschen C, Aicher A, Dernbach E, Zeiher AM, Dimmeler S (2003) Relevance of monocytic features for neovascularization capacity of circulating endothelial progenitor cells. Circulation 108: 2511-2516. http://dx.doi.org/ 10.1161/01. CIR.0000096483.29777.50.

Urbich C, Dimmeler S (2004) Endothelial progenitor cells: characterization and role in vascular biology. Circ Res 95: 343-353. http:// dx.doi.org/10.1161/01.RES.0000137877.89448.78

Vajkoczy P, Blum S, Lamparter M, Mailhammer R, Erber R, Engelhardt B, Vestweber D, Hatzopoulos AK (2003) Multistep nature of microvascular recruitment of ex vivo-expanded embryonic endothelial progenitor cells during tumor angiogenesis. J Exp Med 197: 1755-1765. http://dx.doi.org/10.1084/jem.20021659.

Vasa M, Fichtlscherer S, Aicher A, Adler K, Urbich C, Martin H, Zeiher AM, Dimmeler S (2001) Number and migratory activity of circulating endothelial progenitor cells inversely correlate with risk factors for coronary artery disease. Circ Res. 89: E1-E7. http://dx.doi. org $/ 10.1161 /$ hh1301.093953.

Wang $\mathrm{CH}$, Cherng WJ, Yang NI, Hsu CM, Yeh CH, Lan YJ, Wang JS, Verma S (2008) Cyclosporine increases ischemia-induced endothelial progenitor cell mobilization through manipulation of the CD26 system. Am J Physiol Regul Integr Comp Physiol 294: R811-R818. http:// dx.doi.org/10.1152/ajpregu.00543.2007.

Werner N, Junk S, Laufs U, Link A, Walenta K, Bohm M, Nickenig G (2003) Intravenous transfusion of endothelial progenitor cells reduces neointima formation after vascular injury. Circ Res 93: e17-24. http://dx.doi.org/10.1161/01.RES.0000083812.30141.74.

Werner N, Kosiol S, Schiegl T, Ahlers P, Walenta K, Link A, Böhm M, Nickenig G (2005) Circulating endothelial progenitor cells and cardiovascular outcomes. N Engl J Med 353: 999-1007. http://dx. doi.org/10.1056/NEJMoa043814.

Westerweel PE, Hoefer IE, Blankestijn PJ, de Bree P, Groeneveld D, van Oostrom O, Braam B, Koomans HA, Verhaar MC (2007) End-stage renal disease causes an imbalance between endothelial and smooth muscle progenitor cells. Am J Physiol Renal Physiol 292: F1132 -F1140. http://dx.doi.org/10.1152/aiprenal.00163.2006.

Xiao Q, Kiechl S, Patel S, Oberhollenzer F, Weger S, Mayr A, Metzler B, Reindl M, Hu Y, Willeit J, Xu Q (2007) Endothelial progenitor cells, cardiovascular risk factors, cytokine levels and atherosclerosis - results from a large population-based study. PLoS One 2: e975. http://dx.doi.org/10.1371/journal.pone.0000975 .

Yu Y, Fukuda N, Yao EH, Matsumoto T, Kobayashi N, Suzuki R, Tahira Y, Ueno T, Matsumoto K (2008) Effects of an ARB on endothelial progenitor cell function and cardiovascular oxidation in hypertension. Am J Hypertens 21: 72-77. http://dx.doi.org/10.1038/ ajh. 2007.5 .

Zhao J, Bolton EM, Randle L, Bradley JA, Lever AM (2014) Functional characterization of late outgrowth endothelial progenitor cells in patients with end-stage renal failure. Transpl Int 27: 437-451. http:// dx.doi.org/10.1111/tri.12277.

Zhu XY, Urbieta Caceres VH, Favreau FD, Krier JD, Lerman A, Lerman LO (2011) Enhanced endothelial progenitor cell angiogenic potency, present in early experimental renovascular hypertension, deteriorates with disease duration. J Hypertens 29: 1972-1979. http://dx.doi.org/10.1097/HJH.0b013e32834ae611. 